\title{
Production, Growth and International Competitiveness of Mexican Honey
}

\author{
Danae Duana Avila, Karina Valencia Sandoval, Ma. Del Rosario García Velázquez, \\ Enrique Vázquez Fernández
}

Universidad Autónoma del Estado de Hidalgo, Pachuca de Soto, México

Email:duana@uaeh.edu.mx

How to cite this paper: Avila, D. D., Sandoval, K. V., Velázquez, Ma. D. R. G., \& Fernández, E. V. (2019). Production, Growth and International Competitiveness of Mexican Honey. Advances in Applied Sociology, 9, 153-162.

https://doi.org/10.4236/aasoci.2019.95013

Received: April 10, 2019

Accepted: May 27, 2019

Published: May 30, 2019

Copyright $\odot 2019$ by author(s) and Scientific Research Publishing Inc. This work is licensed under the Creative Commons Attribution International License (CC BY 4.0).

http://creativecommons.org/licenses/by/4.0/

\begin{abstract}
The objective of this research is to analyze the competitiveness and participation that the main honey exporting countries have, and their behavior in the global market, opening the way to other emergent economies in the international blocks battle and the economic globalization. The American study case is shown because it is the main buyer and for the importance that its providers have in the commercial balance, contrasting the competitive performance between Mexico and its competitors using the competitiveness of exportations in the market method for the 2001-2006 period. The national importance of the exportations to the American market of the apiculture sector for Mexico during the last 16 years is approached in the first section; in the second section it is shown how apiculture has developed internationally using a disclosed advantage index, in the third section the behavior of exportations and importations is shown, and finally a competitiveness analysis is made using the constant market participation analysis method (CMPAM).
\end{abstract}

\section{Keywords}

Economic Globalization, Apiculture Sector, Competitiveness Analysis

\section{Introduction}

The competitiveness analysis started in the 17th century, classic economists made reference to the absolute advantage, starting with Adam Smith who made researches about the specialization of a country as a way to obtain better profits by focusing on commerce as a the generator of international growth, according to Smith the absolute advantage was found in the specialization of a country as a way of minimizing the absolute costs (Lombana \& Rozas, 2009), afterwards David Ricardo sustained that commerce is a source of mutual benefits for the 
countries. Even though both theories are arguable, the truth is that Adam Smith and David Ricardo set the ground for international commerce that is now taken into account by the specialists who have also signaled that the inter and intra industrial commerce can impulse the economic growth of a nation (García, \& Maldonado, 2013).

On the other hand, Michael Porter set the bases of competitiveness in his work "The competitiveness advantage of nations" where he stressed the fact that the abundance of a country depends directly on its competitiveness based on its productivity, he also signals that among the macroeconomic aspects that open the way for competitiveness in a quantitative way we may find the commercial performance and the payment balance (Lombana \& Rozas, 2009).

\section{Apiculture in Mexico}

The bee-keeping activity in Mexico is traditionally found in the south of the country for its geographic characteristics that allow to create the proper habitat and bee production through the variety and availability of the flora and fauna, making Yucatan the main honey producing entity followed by Campeche (SIAP-SAGARPA, 2017) (Figure 1).

Economic and socially, apiculture has great importance because of the number of jobs in the rural countryside, and also because a great part of the production is destined to the international commerce allowing to obtain foreign currency, just between 1995 and 2008 apiculture captured in average $12.4 \%$ of foreign currency for the national livestock subsector, while in the agriculture and livestock sector it represented the 12.4\% (Magaña \& Leyva, 2011).

Magaña, Moguel, Sanginés, \& Leyva (2012) hold that Mexico is the sixth world producer, placed below China, Argentina, Turkey, Ukraine, and the United States, in terms of exportation it is placed below China and Argentina, with the main destiny being the European market where it is recognized for its quality and nutritional properties.

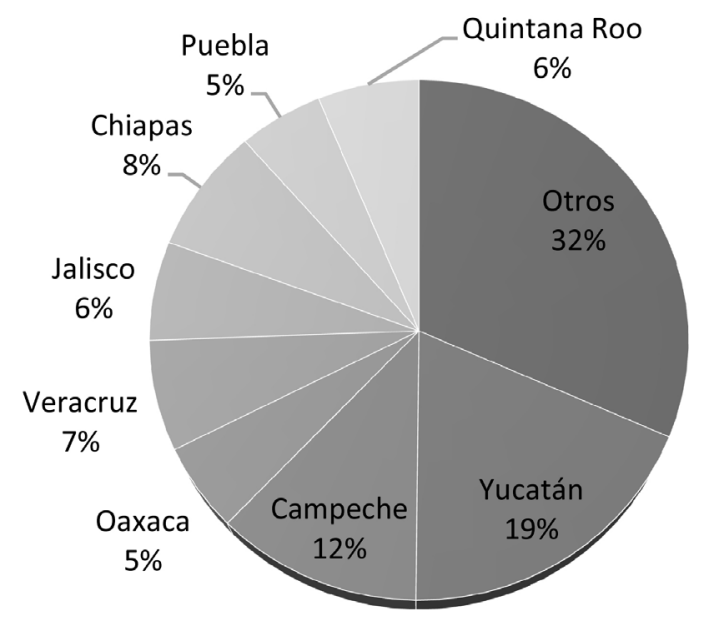

Figure 1. Bee population (hives). Source: own making with SIAP-SAGARPA data (2017). 
The food, agriculture and fishing information service (SIAP-SAGARPA, 2016) points out that nowadays that $68 \%$ of the production is exported, its main destinations are Germany, The United States, and The United Kingdom.

\section{Theoretical Premise}

Few authors have studied honey in the international market; most of the researches are focused in the local market.

Magaña \& Leyva (2011) determined that the production costs of honey delve into the payment of the workforce and the purchase of the consumable goods, causing a variation in the profitability of the apiculture exploitation. However, besides this, their results show profitability maintaining its social and economic importance and showing its competitiveness linked to the exterior.

Other experts (González, Rebollar, Hernández, \& Guzmán, 2014) have calculated the commercialisation margins of the product determining that it is the retailers who obtain in average the biggest margin in August, October and January.

Contreras, Pérez, Echazarreta, Cavazos, Macías, \& Tapia (2013) focused in the apiculture at Jalisco mentioning the loss of competitiveness in the international market adding origin variables such as high production costs, the difficult access to credit and the laggard of technological innovation. They also mention the main problems that the beekeeper faces and the ones where he may have an influence or not: climate change, African bees, lack of training and organization of the beekeepers, hive diseases (varroosis and loques) retailers and the abundant competition.

On the other hand, Magaña, Saginés, Lara, Salazar, \& Leyva (2017) studied the competitiveness of honey concluding that there is international participation and presence of Mexican honey even with the negative environmental events.

With all the previous information, this paper object if is to quantify the worldwide competitiveness of Mexican honey, in its main exporting destinations (Germany, The United Kingdom, and The United States) facing Argentina (its main competitor in Latin America) under the hypothesis that Mexican honey is competitive in relation to its competitors.

\section{Methodology}

To achieve the set goal, data from honey importations and exportations to the main destinations was used, once they were obtained, the rate of comparative and revealed advantage (VRE) was analyzed, this rate was implemented by Balassa (1965, quoted by Omaña, Almora, Cruz, Hoyos, Quintero, \& Fortis, 2014) its results show that while the magnitude grows, the nation is considered more specialized a competitive.

The rate $V R E$ is defined as:

$$
V R E_{a i}=\frac{\left(X_{a i} / X_{n i}\right)}{\left(X_{a r} / X_{n r}\right)}
$$

where: 
$V R E_{a i}=$ is the relative advantage of the merchandise "a" exportations in the country "i";

$X_{a i}=$ is the value of the merchandise " $a$ " exportations in the country " $i$ ";

$X_{n i}=$ is the value of the total exportations (except for merchandise " $a$ ") in the country;

$X_{a r}=$ is the value of the merchandise " $a$ " exportations in the world (except for the country " $i$ ");

and finally

$X_{n r}=$ is the total value of exportations (except for merchandise " $a$ ") in the world (except for the country " $i$ ").

Omaña et al. (2014) indicate the possibility of identifying the VER for a specific market using the value of importations.

With these indicators we know what the competitiveness of Mexican honey exportations have represented thorough time. Then the rate of relative advantage of exportations proposed by Vollrath (1991) is calculated, this is a way of measuring the competitive advantages for agricultural products through the determination of a rate for specific agricultural products that uses real data from commerce and allows to differentiate the countries with a competitive advantage for a specific product from those who don't have it, and it also makes it easier to compare the trends of revealed competitiveness among the countries that compete in the market with this product.

$$
s=\frac{q}{Q}
$$

where the meaning of each variable is:

$s=$ Market participation of a specific country.

$q=$ Exportations from the country to the reference market.

$Q=$ Exportations from the group of competitor countries that export to the reference market (Standard).

Take the previous formula and find $q$ and then make a differentiation regarding time, obtaining:

$$
\begin{gathered}
\Delta q=q^{1}-q^{0}=s^{0} \Delta Q+Q^{1} \Delta s \\
\Delta q=s^{0} \Delta Q+\left[\sum_{i} s_{i}^{0} \Delta Q_{i}-s^{0} \Delta Q\right] \\
+\left[\sum_{i} \sum_{j} s_{i j}^{0} \Delta Q_{i j}-\sum_{i} s_{i}^{0} \Delta Q_{i}\right] \sum_{i} \sum_{j} Q_{i j}^{1} \Delta s_{i j} \\
s^{0}=\frac{q^{0}}{Q^{0}}=\frac{\sum_{i} s_{i}^{0} Q_{i}^{0}}{\sum_{i} Q_{i}^{0}} \\
s^{1}=\frac{q^{1}}{Q^{1}}=\frac{\sum_{i} s_{i}^{1} Q_{i}^{1}}{\sum_{i} Q_{i}^{1}} \\
s^{H}=\frac{q^{H}}{Q^{H}}=\frac{\sum_{i} s_{i}^{0} Q_{i}^{1}}{\sum_{i} Q_{i}^{1}} \\
\text { Structural Effect }=s^{H}-s^{0}=\frac{\sum_{i} s_{i}^{0} Q_{i}^{1}}{\sum_{i} Q_{i}^{1}}-\frac{\sum_{i} s_{i}^{0} Q_{i}^{0}}{\sum_{i} Q_{i}^{0}}
\end{gathered}
$$




$$
\begin{aligned}
\frac{\sum_{i} s_{i}^{1} Q_{i}^{1}}{Q^{1}}-\frac{\sum_{i} s_{i}^{0} Q_{i}^{0}}{Q^{0}}= & \frac{\sum_{i} s_{i}^{0} Q_{i}^{1}}{Q^{1}}-\frac{\sum_{i} s_{i}^{0} Q_{i}^{0}}{Q^{0}}+\frac{\sum_{i} s_{i}^{1} Q_{i}^{0}}{Q^{1}}-\frac{\sum_{i} s_{i}^{0} Q_{i}^{0}}{Q^{1}} \\
& +\frac{\sum_{i} s_{i}^{1} Q_{i}^{1}}{Q^{1}}-\frac{\sum_{i} s_{i}^{0} Q_{i}^{1}}{Q^{1}}-\frac{\sum_{i} s_{i}^{1} Q_{i}^{0}}{Q^{1}}+\frac{\sum_{i} s_{i}^{0} Q_{i}^{0}}{Q^{1}} \\
\Delta Q= & r Q^{0}-Q^{0}+\left[\sum_{i} r_{i} Q_{i}^{0}-r Q^{0}\right]+\left[\sum_{i} \sum_{j} r_{i j} Q_{i j}^{0}-\sum_{i} r_{i} Q_{i}^{0}\right] \\
+ & {\left[Q^{1}-\sum_{i} \sum_{j} r_{i j} Q_{i j}^{0}\right] } \\
\Delta Q_{i}=\sum_{i} \Delta q_{j}= & \sum_{i} q_{i j}\left(\frac{\Delta M}{M}\right)+\sum_{i} q_{i j}\left[\left(\frac{\Delta M_{j}}{M_{j}}\right)-\left(\frac{\Delta M}{M}\right)\right] \\
& +\sum_{i} q_{i j}\left[\left(\frac{\Delta q_{i j}}{q_{i j}}\right)-\left(\frac{\Delta M_{j}}{M_{j}}\right)\right]
\end{aligned}
$$

Demand effect

Structural effect

Competitiveness effect

\section{Results}

Rate of comparative revealed rate (VRE).

Grid 1 shows the VRE of Mexico and Argentina, in the international and

\begin{tabular}{|c|c|c|c|c|}
\hline \multirow{2}{*}{ Year } & \multicolumn{2}{|c|}{ Mexico } & \multicolumn{2}{|c|}{ Argentine } \\
\hline & International & Germany & International & Germany \\
\hline 2001 & 2.37 & 55.44 & 35.92 & 165.32 \\
\hline 2002 & 3.47 & 54.96 & 39.55 & 148.74 \\
\hline 2003 & 3.20 & 34.94 & 41.50 & 161.56 \\
\hline 2004 & 3.24 & 47.36 & 37.01 & 136.84 \\
\hline 2005 & 2.17 & 34.82 & 46.75 & 195.96 \\
\hline 2006 & 2.79 & 23.58 & 47.71 & 167.96 \\
\hline 2007 & 3.20 & 29.80 & 37.06 & 134.55 \\
\hline 2008 & 3.51 & 28.33 & 31.63 & 131.17 \\
\hline 2009 & 3.42 & 30.14 & 27.86 & 116.57 \\
\hline 2010 & 2.87 & 30.39 & 25.74 & 100.50 \\
\hline 2011 & 2.75 & 34.97 & 28.64 & 64.61 \\
\hline 2012 & 2.87 & 32.94 & 28.15 & 74.40 \\
\hline 2013 & 2.70 & 38.05 & 25.54 & 39.03 \\
\hline 2014 & 3.01 & 42.81 & 24.29 & 35.47 \\
\hline 2015 & 2.98 & 43.80 & 20.96 & 34.70 \\
\hline 2016 & 1.77 & 27.58 & 20.67 & 74.79 \\
\hline
\end{tabular}
German markets, it is observed that, even if Argentina shows rates with higher relevance in the international market, showing more competitiveness and that justifies its placement in the global market of honey producers, a negative trend is shown in its numbers, it is the same situation for Mexico. The results contrast

Grid 1. Rate of comparative revealed rate (VRE).

Source: own making. 
with the description of Magaña et al. (2017) who reported Mexico as the 1st place in honey competitiveness among the producing nations; however it coincides when it is affirmed that "National production has experienced an evident diminution". The same event happens in the destination market they share, the competitiveness of both countries has decreased as the period of study goes by. The merchandises flux has revealed less efficiency in Mexico and loss of competitiveness for both.

In the last 100 years, the gradual industrialization of the regions has taken to important changes in terms of demand, that derivate from the exportation of manufactured products. On the other side, industrial equipment and the modern transportation are important for the consumable goods of the textile industry, it is also well known that with the pass of time, producing nations have shown different degrees of adaptability to this process.

The purpose of this investigation is to make an analysis of the changes in the worldwide demand of honey exportations and the competitive position of the main producing nations in the world. With the objective of determining the market fee changes, the global market may also be explained by the composition of each product from the country's exportations or by the fee of the global market of a country of the global market. It is also explained by the difference between the hypothetical market fee and the change fee, caused by the structural changes in the international market. The difference between real (final) and hypothetical, the fee was referred on how the change was caused by changes in competitiveness. This method will later be known as "constant analysis of the market's actions" (Fagerberg \& Gunnar, 1985).

The Shift-Share technique has been one of the most used methods when it comes to analyzing the growth in employment or rent of certain region. Even if it has an elevated popularity degree, that has been observed for decades within its multiple application, it has been highly criticized. The APCM it's an alternate term of the widely spread "change-participation" analysis (shift-share analysis) initially used by Creamer (1943). Also, the constant market participation method, CMS, is used; this method was popularized by Leamer and Stern (1970), which is a statistic technique that allows decomposing the growth in exportations to study their behavior and evaluate the degree that the structural factors and competitiveness explain its development in certain period.

Grid 2 shows the change in a country's exportation that is composed from the addition of 3 effects: structural effect, competitiveness effect or residual, and interaction effect or second order, which are determined by the expression. This means that the sales of the honey market have increased up to $234 \%$ in 2016, in the 2001 period of analysis, the result is independent from the increase or decrease that each enterprise has experienced.

Grid 3 shows that the German importations from Mexico have increased in the period analysis to a $220 \%$ on the other hand if we compare them with the Argentineans we can see that the increase was of $112 \%$ which represents un advantage for Mexico, that has a $232 \%$ raise in the analyzed product. 
D. D. Avila et al.

Grid 2. Mexico total honey exportations and participations (millions of dollars).

\begin{tabular}{|c|c|c|c|c|c|c|c|}
\hline Year & $\begin{array}{c}\text { Total international } \\
\text { exportations }\end{array}$ & $\begin{array}{c}\text { Honey } \\
\text { international } \\
\text { exportations }\end{array}$ & $\begin{array}{l}\text { Mexico's total } \\
\text { exportations }\end{array}$ & $\begin{array}{l}\text { Total honey } \\
\text { exportations }\end{array}$ & $\begin{array}{c}\text { Honey } \\
\text { exportations to } \\
\text { Germany }\end{array}$ & $\begin{array}{c}\text { Honey } \\
\text { exportations } \\
\text { to USA }\end{array}$ & $\begin{array}{c}\text { Honey } \\
\text { exportations } \\
\text { to the UK }\end{array}$ \\
\hline 2001 & $6,115,023,861$ & 457,500 & $158,386,217$ & 28,074 & 15,576 & 4206 & 1589 \\
\hline 2002 & $6,404,339,571$ & 719,123 & $160,750,540$ & 62,654 & 27,143 & 21,059 & 5471 \\
\hline 2003 & $7,463,959,157$ & 960,487 & $164,906,509$ & 67,947 & 30,119 & 19,572 & 5146 \\
\hline 2004 & $9,086,145,834$ & 855,816 & $187,980,442$ & 57,408 & 34,444 & 7412 & 8783 \\
\hline 2005 & $1.0343 \mathrm{E}+10$ & 708,646 & $214,207,306$ & 31,836 & 16,414 & 2222 & 4382 \\
\hline 2006 & $1.1953 \mathrm{E}+10$ & 829,915 & $249,960,546$ & 48,381 & 24,618 & 4735 & 6033 \\
\hline 2007 & $1.3778 \mathrm{E}+10$ & 894,129 & $271,821,215$ & 56,454 & 31,346 & 5496 & 8426 \\
\hline 2008 & $1.5973 \mathrm{E}+10$ & $1,307,665$ & $291,264,809$ & 83,789 & 48,000 & 3788 & 11,274 \\
\hline 2009 & $1.2317 \mathrm{E}+10$ & $1,272,840$ & $229,712,337$ & 81,239 & 49,935 & 4580 & 10,013 \\
\hline 2010 & $1.5061 \mathrm{E}+10$ & $1,488,506$ & $298,305,075$ & 84,743 & 45,925 & 9799 & 8250 \\
\hline 2011 & $1.8074 \mathrm{E}+10$ & $1,699,967$ & $349,326,582$ & 90,359 & 49,474 & 9430 & 8688 \\
\hline 2012 & $1.846 \mathrm{E}+10$ & $1,763,852$ & $370,706,658$ & 101,497 & 55,471 & 19,707 & 9715 \\
\hline 2013 & $1.896 \mathrm{E}+10$ & $2,078,161$ & $379,949,273$ & 112,352 & 58,644 & 20,262 & 14,298 \\
\hline 2014 & $1.897 \mathrm{E}+10$ & $2,334,422$ & $396,881,846$ & 147,037 & 61,365 & 28,602 & 11,620 \\
\hline 2015 & $1.6523 \mathrm{E}+10$ & $2,274,653$ & $380,600,857$ & 155,986 & 76,658 & 21,400 & 15,551 \\
\hline 2016 & $1.5862 \mathrm{E}+10$ & $2,244,747$ & $373,882,951$ & 93,725 & 42,647 & 23,425 & 9518 \\
\hline
\end{tabular}

Source: own making with trade map data from different years.

Grid 3. Mexico total honey importations and participations (millions of dollars).

\begin{tabular}{|c|c|c|c|c|c|c|c|}
\hline Year & $\begin{array}{c}\text { German } \\
\text { importations } \\
\text { in Mexico }\end{array}$ & $\begin{array}{l}\text { Total value of } \\
\text { German } \\
\text { importations } \\
\text { in Mexico }\end{array}$ & $\begin{array}{l}\text { Value of honey } \\
\text { importations in } \\
\text { Germany }\end{array}$ & $\begin{array}{c}\text { Total value of } \\
\text { importations in } \\
\text { Germany }\end{array}$ & $\begin{array}{l}\text { Value of the } \\
\text { German honey } \\
\text { importations in } \\
\text { Argentina }\end{array}$ & $\begin{array}{l}\text { Total value of } \\
\text { the German } \\
\text { importations } \\
\text { in Argentina }\end{array}$ & $\begin{array}{c}\text { Honey } \\
\text { Importations } \\
\text { value in } \\
\text { Germany }\end{array}$ \\
\hline 2001 & 17,734 & $1,384,541$ & 112,286 & $486,022,068$ & 28,702 & 751,475 & 112,286 \\
\hline 2002 & 22,390 & $1,202,158$ & 166,189 & $490,450,056$ & 44,300 & 878,976 & 166,189 \\
\hline 2003 & 24,475 & $1,745,656$ & 241,470 & $601,761,022$ & 70,153 & $1,082,124$ & 241,470 \\
\hline 2004 & 30,175 & $2,020,455$ & 226,479 & $718,150,018$ & 53,101 & $1,230,478$ & 226,479 \\
\hline 2005 & 19,237 & $2,570,031$ & 167,654 & $779,819,058$ & 51,785 & $1,229,159$ & 167,654 \\
\hline 2006 & 15,115 & $3,787,160$ & 156,119 & $922,213,393$ & 46,388 & $1,631,426$ & 156,119 \\
\hline 2007 & 27,609 & $5,110,368$ & 192,036 & $1,059,307,813$ & 50,068 & $2,052,646$ & 192,036 \\
\hline 2008 & 36,382 & $6,248,455$ & 247,517 & $1,204,209,300$ & 67,705 & $2,511,118$ & 247,517 \\
\hline 2009 & 36,599 & $4,448,935$ & 256,093 & $938,363,080$ & 64,344 & $2,022,483$ & 256,093 \\
\hline 2010 & 40,155 & $4,875,634$ & 289,073 & $1,066,816,800$ & 63,815 & $2,343,378$ & 289,073 \\
\hline 2011 & 46,676 & $6,052,116$ & 277,955 & $1,260,297,500$ & 45,034 & $3,160,171$ & 277,955 \\
\hline 2012 & 46,406 & $5,616,998$ & 291,269 & $1,161,213,200$ & 47,575 & $2,549,398$ & 291,269 \\
\hline 2013 & 55,806 & $5,246,946$ & 331,859 & $1,187,314,600$ & 24,394 & $2,236,347$ & 331,859 \\
\hline 2014 & 56,108 & $4,944,296$ & 322,029 & $1,214,955,700$ & 20,245 & $2,153,462$ & 322,029 \\
\hline 2015 & 67,817 & $5,038,653$ & 325,011 & $1,057,616,386$ & 18,101 & $1,697,239$ & 325,011 \\
\hline 2016 & 39,144 & $5,781,836$ & 260,348 & $1,060,672,017$ & 32,252 & $1,756,872$ & 260,348 \\
\hline
\end{tabular}

Source: own making with trade map data from different years. 
For the honey exportation competitiveness, first a complete analysis of its behavior is made, from the value at production, the evolution of exportations, importations, and this give us the first approach.

Grid 4 shows that the method breaks down into three parts the raise in Mexico's honey exportations to the American, German and British markets during the period of study.

The first part called structural effect shows the impact of the growth of the exportations of the specific goods basket that the country exports. This effect is measured by applying to each exporting branch, the growth they registered in the total importer market, substracting the growth that would result if these branches would have expanded to the global rate that made it the total importer market.

A positive value is obtained when the Mexican exportations to the American market are controlled by merchandises that have a higher increase in exportation than the increase level of the manufacture of the United States.

The competitiveness effect has the most important meaning in this method. It tries to explain the changes in the country's participation in the global market that results from the next elements: 1) the variation of the relative prices of the products; 2 ) The capacity that the exporting country has to attend promptly and efficiently the needs of global demand; 3) the technological innovations; and 4) the incidence of trade politics.

The structural effect, the competitiveness effect and the structure effect are positive for all the countries, which represents the raise of honey demand has favored the countries that have a positive rate. However the growth effect and the market effect offer an improvement of the competitiveness to all the countries, even if the competitiveness effect turned out to be significant to the positive rates.

The structural effect for Mexico is 10,185, Germany 10,639, United States 35,245 and United Kingdom 10,215, the competitiveness effect favors the United States with 23,524 and the growth effect is better for the United Kingdom. 75,689 are positive for all countries, which represents that the increased honey demand has favored countries that have a positive index. However, in the expansion area of the United States has been favored with 7869, Mexico shows an area of opportunity.

Grid 4. Market participation.

\begin{tabular}{cccccc}
\hline Effect & Equation & Mexico & Germany & United States & United Kingdom \\
\hline Structural effect & $\mathrm{Sj} 0 \Delta \mathrm{Qj}$ & 10,185 & 10,639 & 35,245 & 10,215 \\
Competitiveness effect & $\Delta \mathrm{SjQj} 0$ & 19,202 & 20,203 & 23,524 & 15,693 \\
Growth effect & $\mathrm{St0} \Delta \mathrm{Qj}$ & 12,589 & 7846 & 32,546 & 75,689 \\
& $\mathrm{Sj0} \Delta \mathrm{Qj}$ & -2891 & 4128 & 7869 & 4250 \\
Market effect & $-\mathrm{St0DQj}$ & & & & \\
& & & & &
\end{tabular}

Source: own making with trade map data: 2001-2016. 


\section{Conclusion}

Mexican honey exportations have grown rapidly from the mid 80's and Mexico's participation in the global market with this product has risen considerably in a relatively short period.

The analysis presented in this work suggests that the growth of Mexican honey exportations is associated with an extraordinary improvement of its competitiveness in relation to the other competitor countries.

This higher competitiveness derives from its advantages given by the low cost of the manufacture and the favorable natural conditions, best production techniques and the exterior market demand.

The German and British market study cases suggest that a great part of the honey exportations growth during the 2001-2016 period can be attributed to the improvements in competitiveness. However, the results of this work suggest that this raise is associated with general factors but not with the specific competitiveness of the American market.

On the contrary, the German and British competitiveness in this specific market seems to have increased. This seems to show that these countries have certain advantages compared to Mexico, such as lower transportation costs, higher efficiency in the commercialization system, and a preference in tax payments from the United States.

According to the data that was obtained, we may project that the international honey demand will keep growing and Mexico disposes of potential advantages to increase its participation in the market. However, the traditional, comparative advantages are not enough to maintain themselves in specific markets like Germany, where the trade costs are important to compete with other offers. If Mexico wishes to sustain or expand its participation in the United Kingdom's honey market efforts, it must be made to improve the efficiency of its commercialization and transportation system and gain access to the free tax market.

\section{Conflicts of Interest}

The authors declare no conflicts of interest regarding the publication of this paper.

\section{References}

Balassa, B. (1965). Trade Liberalization and "Revelead" Comparative Advantage. Manchester: Manchester School. https://doi.org/10.1111/j.1467-9957.1965.tb00050.x

Contreras, F., Pérez, B., Echazarreta, C. M., Cavazos, J., Macías, J. O., \& Tapia, J. M. (2013). Características y situación actual de la apiculturaen las regiones Sur y Sureste de Jalisco, México. Revistamexicana de cienciaspecuarias, 4, 387-398.

Creamer, D. (1943). Shifts of Manufacturing Industries. Industrial Location and National Resources, 85-104.

Fagerberg, J., \& Gunnar, S. (1985). The Method of Constant-Market-Shares Analysis Revisited. En. Discussion Paper.

García, R., \& Maldonado, A. (2013). Competitividad del calzado de cuerocolombiano: 
perspectiva de la ventajacomparativarevelada (1980-2008). En: Dimensiónempresarial, 11, 77-91. https://doi.org/10.15665/rde.v11i1.162

González, F., Rebollar, S., Hernández, J., \& Guzmán, E. (2014). La comercialización de la mielen el sur del Estado de México. Revista Mexicana de Agronegocios, 34, 806-815.

Leamer, E. E., \& Stern, R. M. (1970). Quantitative International Economics (pp. 171-183). Boston: Allyn and Bacon, Inc.

Lombana, J., \& Rozas, S. (2009). Marco analítico de la competitividad. Fundamentos para el estudio de la competitividad regional. En: Pensamiento \& Gestión, 26, 1-38.

Magaña, M. A., Moguel, Y. B., Sanginés, J. R., \& Leyva, C. E. (2012). Estructura e importancia de la cadenaproductiva y comercial de la mielen México. Revistamexicana de cienciaspecuarias, 3, 49-64.

Magaña, M., \& Leyva, C. (2011). Costos y rentabilidad del proceso de producciónapícolaen México. En: Contaduría y Administración, 235, 99-119.

Magaña, M., Sanginés, J., Lara, P., Salazar, L., \& Leyva, C. (2017). Competitividad y participación de la mielmexicanaen el mercadomundial. Revista Mexicana de Ciencias Pecuarias, 8, 43-52. https://doi.org/10.22319/rmcp.v8i1.4304

Omaña, J., Almora, I., Cruz, B., Hoyos, G., Quintero, J., \& Fortis, M. (2014). Competitividad de la carne de ganadobovino entre los paísesmiembros del TLCAN 1997-2008. Revista Mexicana de CienciasAgrícolas, 5, 175-189.

https://doi.org/10.29312/remexca.v5i2.958

Servicio de InformaciónAgroalimentaria y Pesquera. Secretaría de Agricultura, Ganadería, Desarrollo Rural, Pesca y Alimentación (SIAP-SAGARPA) (2016). México, paísexportador de miel.

http://www.gob.mx/siap/articulos/mexico-pais-exportador-de-miel

Servicio de InformaciónAgroalimentaria y Pesquera. Secretaría de Agricultura, Ganadería, Desarrollo Rural, Pesca y Alimentación (SIAP-SAGARPA) (2017). Población ganadera. http://www.gob.mx/siap/acciones-y-programas/produccion-pecuaria

Vollrath, T. L. (1991). A Theoretical Evaluation of Alternative Trade Intensity Measures of Revealed Comparative Advantage. Weltwirtschaft Archiv, 127, 265-227.

https://doi.org/10.1007/BF02707986 